Vol. 44, N. 3 : pp. $247-255$, September, 2001

ISSN 1516-8913 Printed in Brazil

\title{
Anatomy of Somatic Embryogenesis in Carica papaya L.
}

\author{
Juliana A. Fernando, Murilo Melo, Marli K. M. Soares and Beatriz Appezzato-da-Glória* \\ Depto. de Ciências Biológicas/ESALQ/ USP. Av. Pádua Dias, 11 - 13418-900 - Piracicaba - SP, Brazil
}

\begin{abstract}
Mature zygotic embryos of Carica papaya L. 'Sunrise Solo' were used as explants for embryogenesis induction. The explants were inoculated on Murashige and Skoog culture medium supplemented with $2 \mathrm{mg} \cdot \mathrm{L}^{-1}$ 2,4dichlorophenoxyacetic acid and incubated in darkness at $25+2^{\circ} \mathrm{C}$. Histological analysis of callogenesis and somatic embryogenesis indicated occurrence of direct and indirect somatic embryogenesis development. Direct somatic embryo formation was observed from hypocotyledonary epidermic cells only from explant 18 days after inoculation. Somatic embryos formed indirectly were originated from embryogenic superficial cells of preembryonic complexes located on peripherical and on internal cell layers of callus 49 days after inoculation. Diverse morphological differences including disformed embryos were observed among the somatic embryos.
\end{abstract}

Key words: Anatomy, somatic embryogenesis, papaya

\section{INTRODUCTION}

Carica papaya L. is a member of Caricaceae family with only four native genera. This species occurs in tropical and sub-tropical regions of American and African countries (Cronquist, 1981). The propagation of papaya is by seed, causing considerable variability in a commercial population (Litz \& Conover, 1978). The culture is affected by a range of diseases the most important is caused by Papaya Ringspot Virus (PRSV) (Mahon et al., 1996).

The economic importance of the fruit in Brazil, together with high heterozygosis and susceptibility to diseases have induced investigation on somatic embryogenesis of this species. Considerable interest has been towards genetic improvement by using in vitro techniques such as protoplast culture (Chen \& Chen, 1992), tissue culture (Chen et al., 1987; Fitch, 1993, Litz \& Conover, 1983), somatic hybridization (Jordan et al., 1982/83) and plant transformation using Agrobacterium or microprojectile bombardment (Mahon et al., 1996). However, transformation frequency is strongly influenced by the way shoots are regenerated in vitro (Mukhopadhyay et al., 1992, Detrez et al., 1994). So, histological studies are important for the confirmation of the morphogenetic technique adopted as well as for the determination of cellular types from which somatic embryos are originated (Matsumoto et al., 1996).

Despite of its importance, the characterization of papaya somatic embryogenesis has been little reported in the literature (Chen et al., 1991). Analysis of the origin and development of somatic embryos could give better utilization of papaya somatic embryogenesis toward plant genetic improvement. The aim of this work was to carry out histological analysis of the embryogenic process in vitro in papaya.

\footnotetext{
* Author for correspondence
} 


\section{MATERIAL AND METHODS}

\section{a) Induction of somatic embryogenesis}

Mature zygotic embryos of Carica papaya L. (cv. Sunrise Solo) were used as explants for callus induction. The embryos were washed in ethanol $96^{\circ}$ GL, soaked in a $20 \%$ (Qboa) sodium hypochloride $(\mathrm{v} / \mathrm{v})$ solution and rinsed in distilled water a few minutes. These explants were inoculated in MS culture medium (Murashige \& Skoog, 1962) supplemented with $2 \mathrm{mg} \cdot \mathrm{L}^{-1}$ of $2,4-\mathrm{D}, 0,7 \%$ of agar and $\mathrm{pH}$ adjusted to 5,7 prior to autoclaving. The culture flasks were incubated in total darkness at $25+2^{\circ} \mathrm{C}$.

\section{b) Histological and ultra-structure analysis}

Samples were taken after 0, 3, 6, 8, 10, 12, 14, 16 and 18 days of culture for histological analysis of callus and somatic embryogenesis samples were taken at 18,20, 22, 24, 32, 40, 49 and 56 days of culture.These were fixed in FAA 50 (Sass, 1951) or in Karnovsky solution (Karnovsky, 1965), dehydrated through an ethanol series, embedded in paraffin, sectioned on a rotatory microtome (Sass, 1951) and stained in fuchsin-astra blue combination (Roeser, 1972). Phenolic compounds were identified by using ferric trichloride and starch by using iodide zinc chloride (Johansen, 1940). Samples fixed in Karnovsky solution were dehydrated through an ethanol series and infiltrated with glycol methacrylate resin (Reichert-Jung, Germany). Sections with $5 \mu \mathrm{m}$ were stained with toluidine blue O (Sakai, 1973). Total proteins were identified by using aniline blue black (Fisher, 1968). All samples were analyzed with a Nikon (Labophot) microscope. For scanning electron microscopy, somatic embryos with 40, 49 and 56 days of culture were fixed in Karnovsky solution (Karnovsky, 1965), dehydrated in ethanol, dried to a critical point $\left(\mathrm{CO}_{2}\right)$ and attached to aluminum stubs. Specimens were coated with gold $(40-50 \mathrm{~nm})$ and examined in a Scanning electron microscope (ZEISS, DSM940A, $10 \mathrm{kV}$ ).

\section{RESULTS AND DISCUSSION}

\section{a) Callogenesis:}

Origin of callus cells can affect their physiological state and regenerative capacity that justify the necessity of studies of the morphological events in initial stages of callogenesis (Oka et al., 1995). The authors reported that callus from immature embryos of Hordeum vulgare in MS medium containing $2 \mathrm{mg} . \mathrm{L}^{-1} \quad 2,4-\mathrm{D}$ arose superficially at second day of culture from scutellum epidermis divisions. In the present study mature zygotic embryos of $C$. papaya (Figure 1) inoculated in similar conditions presented alterations only after three days of culture. The first cell divisions for callus formation occurred in the fundamental meristem cells located near the initial procambium along the embryonary axis. On the $6^{\text {th }}$ day of culture, the embryonary axis underwent elongation and together with cell proliferation caused by the cell divisions, the size of the explant practically doubled (Figure 2). The cells located externally to the proliferation area were elongated and highly vacuolated. Some sectors of the hypocotyl protodermis showed discontinuity, mainly on the explant side in contact with the culture medium. By this time the beginning of the caulinar apical meristem development could be observed, therefore, it did not remain latent during the culture as it was reported in H. vulgare por Oka et al. (1995).

The presence of starch was observed in the meristematic cells of the embryonary axis and in the mesophyll cells of the cotyledonary leaf after 8 days of culture. During this phase, the cell proliferation area extended to the cotyledonary leaf (Figure 3). These cell divisions led to the formation of compactly arranged small cells with dense cytoplasm (Figure 3). The most evident alterations in the explant occurred after 12 days of culture and were the increase of the meristematic areas in the embryonary axis and cotyledonary leaf, and the vacuolization of the other fundamental parenchyma cells which started to show a loose arrangement. Such alterations made the epidermis of the young hypocotyl itself detached from the subjacent tissue along the embryonary axis. Moreover, there was a pronounced development of the apical caulinar meristem (Figure 4).

Callus formed after 14 days of culture consisted of two distinct sectors: one with elongated and highly vacuolated cells which conferred friable appearance to the tissue under the epidermis of the explant, and the other occurred internally and showed the presence of compact arranged small meristematic cells with dense cytoplasm. These same remarks were made by Tisserat \& DeMason (1980) when they obtained callus from axillary buds of Phoenix dactylifera inoculated in MS medium containing 2,4-D.

\section{b) Somatic embryogenesis:}


On the $18^{\text {th }}$ day of culture, the explant was highly modified and the hypocotyl protodermis showed complete discontinuity. Somatic embryos originated from individual protodermic cells (Figure 5A). The direct production of somatic embryos from the superficial cells was also observed during the secondary embryogenesis in immature embryos originated from cross-breeding of Carica papaya and C. cauliflora (Chen et al., 1991).

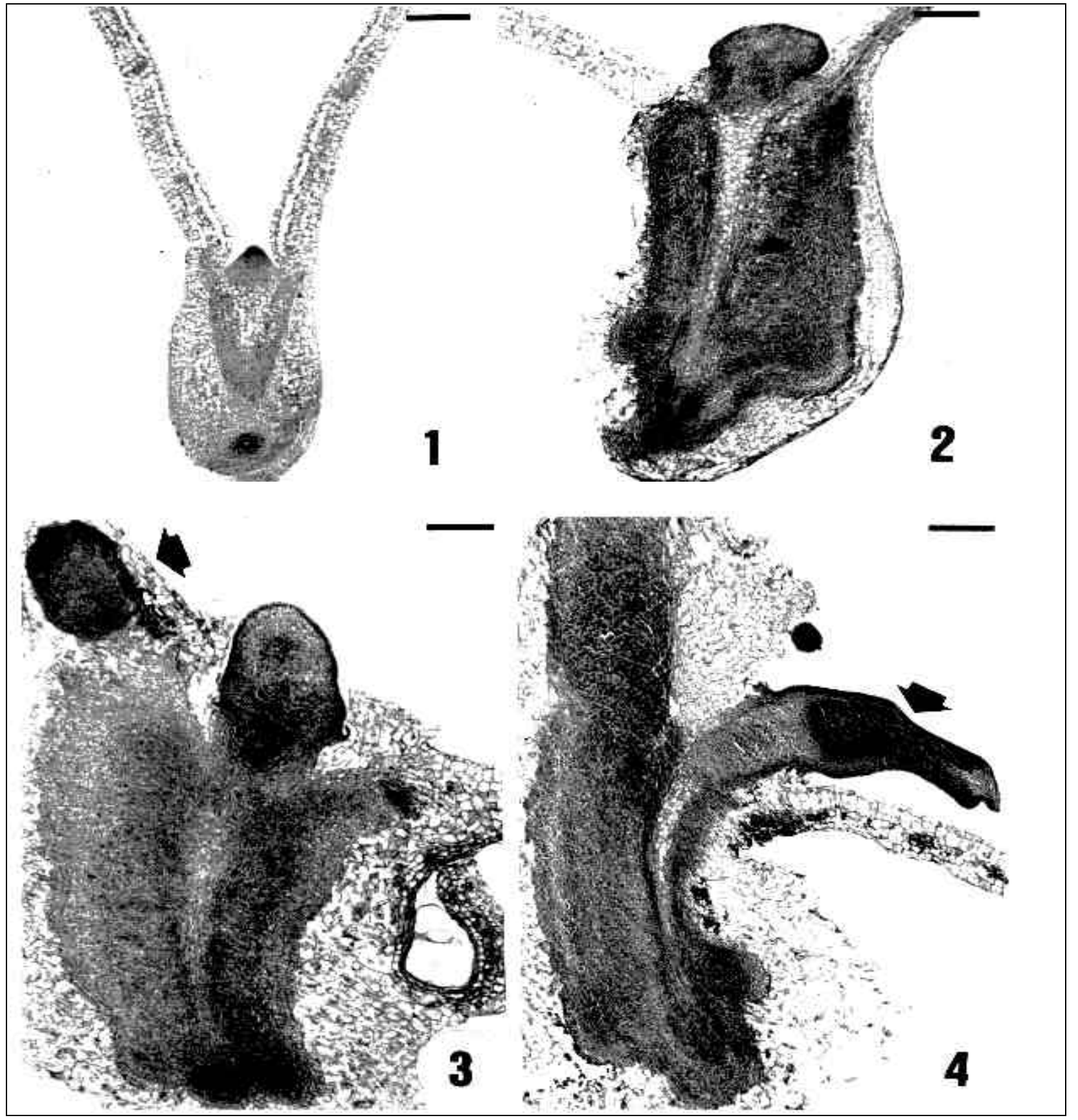

Figures 1-4 - Longitudinal sections of the zygotic embryo of Carica papaya L. after 3, 6, 8 e 12 days of inoculation in MS medium containing 2,0 mg. $\mathrm{L}^{-1}$ 2,4-D and showing the initial phases of the callogenesis and the alteration in the caulinar meristematic apex. 3. Small cells arranged compactly with dense cytoplasm (arrow). 4. Pronounced development of the apical caulinar meristem (arrow) $(\mathrm{bar}=270 \mu \mathrm{m})$. 


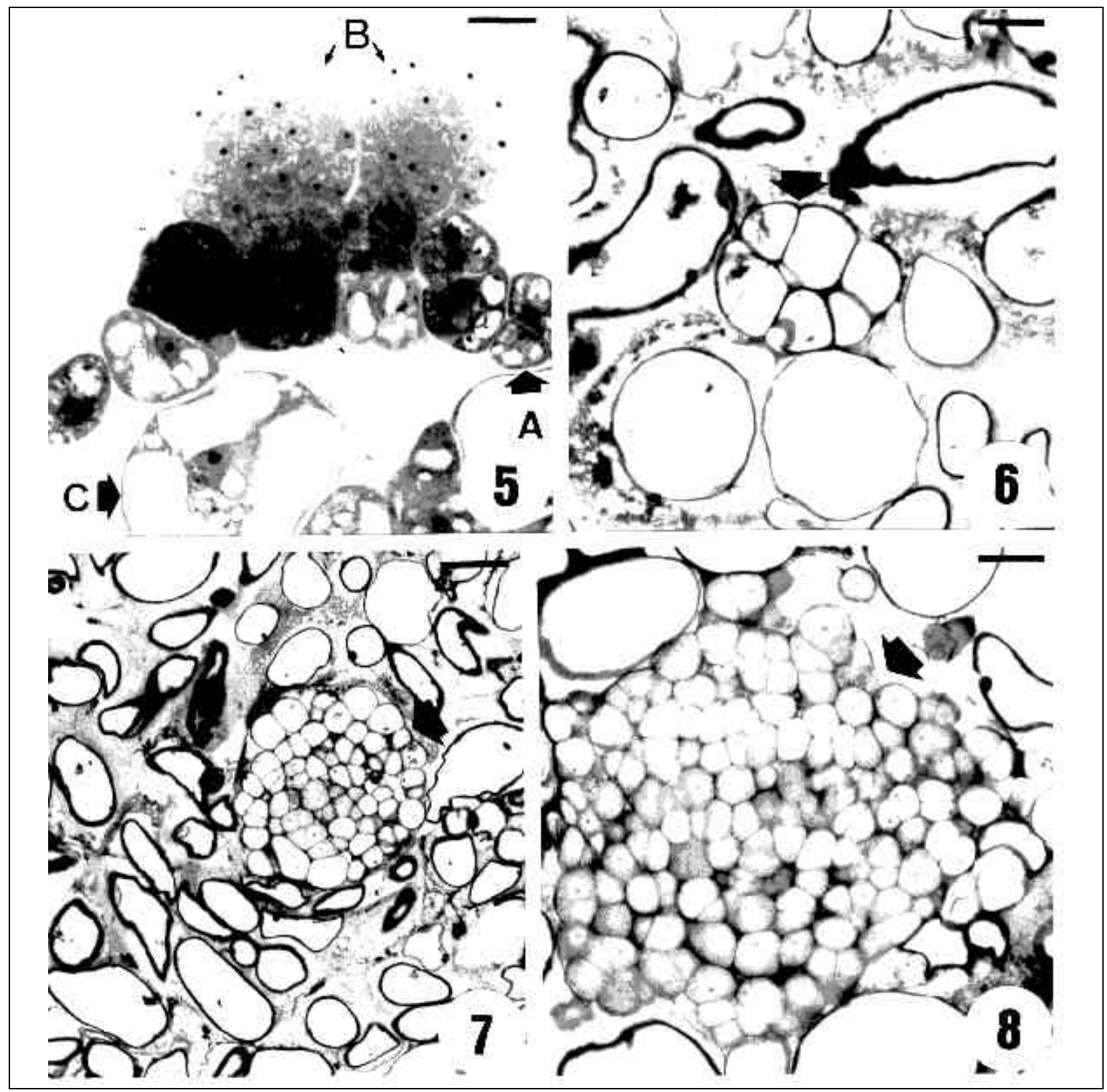

Figures 5-8 - C. papaya L.- 5. Transversal section of the hypocotyl epidermis of the explant at the $18^{\text {th }}$ day of culture in MS medium containing 2,0 mg.L $\mathrm{L}^{-1}$ 2,4-D. The unicellular (A) and direct origin of two globular somatic embryos $(\mathrm{B})(\mathrm{bar}=19 \mu \mathrm{m})$ can be observed. 6-8. Transversal sections of the callus showing the initial phases of pre-embryonic complex formation (arrows) from the cellular pattern indicated by letter $\mathrm{C}$ in Fig. 5. (Fig. 6 bar $=30$ $\mu \mathrm{m}$; Fig. 7 bar $=57 \mu \mathrm{m}$; Fig. 8 bar $=30 \mu \mathrm{m})$.

It has also been observed that when immature zygotic embryos of Trifolium repens were cultivated in vitro in the presence of $\mathrm{N}$-benzil aminopurine (BAP), the epidermic cells of the young hypocotyl produced somatic embryos directly without the intervention of callus stage
(Maheswaran \& Williams, 1985). According to the authors, the proliferation happened only when the epidermis of the embryo detached from the subjacent tissue, although the cells still presented meristematic appearance. The same was verified in 
the present study and also by Cruz et al. (1990) in Feijoa sellowiana.

The embryogenic cells showed small size, dense cytoplasmic contents, large nuclei with prominent enlarged nucleoli, small vacuoles and a profusion of starch grains and total proteins (Figures $5 \mathrm{~A}$ e 5B). The somatic embryos derived from cells presenting the above characteristics was described by Williams \& Maheswaran (1986).

Vacuolated cells were also observed, with a large central nucleus containing one or two prominent nucleoli of the friable sector of the callus (Figure 5C) which started to divide themselves forming meristematic aggregate as showed in figure 6-8. The aggregates were multi-nuclear structures composed of non-vacuolated small cells, compactly arranged, described by Williams \& Maheswaran (1986) as being pre-embryonic complexes. Tisserat \& DeMason (1980) also observed a similar cellular pattern, which originated the aggregates in $P$. dactylifera.

Up to $40^{\text {th }}$ day of culture, it was possible to observe the increase in the number of pre-embryonic complexes (Figure 9). These complexes showed a well defined fragmentation line, formed by cells with thick wall, which established the borderlines between embryogenic cells of the complex and the larger vacuolated cells of the callus (Figure 9). Such characteristic was also reported by Tisserat $\&$ DeMason (1980) considering the $P$. dactylifera complexes, served as a source of somatic embryos. In $C$. papaya this fact could only be confirmed through the analysis of the callus on the $49^{\text {th }}$ day of culture. By this time, somatic embryos were originated from the superficial cells of the preembryonic complexes (Figures 10 and 11) located in the peripheral and internal regions of the callus. Somatic embryos were also originated from embryogenic cells settled on the surface of compact nodules as it was observed in $H$. vulgare (Oka et al., 1995) and Camellia japonica L. (Barciela \& Vieitez, 1993).

Analysis of callus from the $49^{\text {th }}$ day of culture enabled us to observe that somatic embryos appeared associated with the callus in three different ways: a) Somatic embryos in number of one, two or more linked by their bases to the preembryonic complex (Figures 12 and 14); b) isolated somatic embryo showing a suspensor-like structure (Figure 15); c) isolated somatic embryo with its basal portion widely linked to the callus (Figures 16 and 17). The differences mentioned

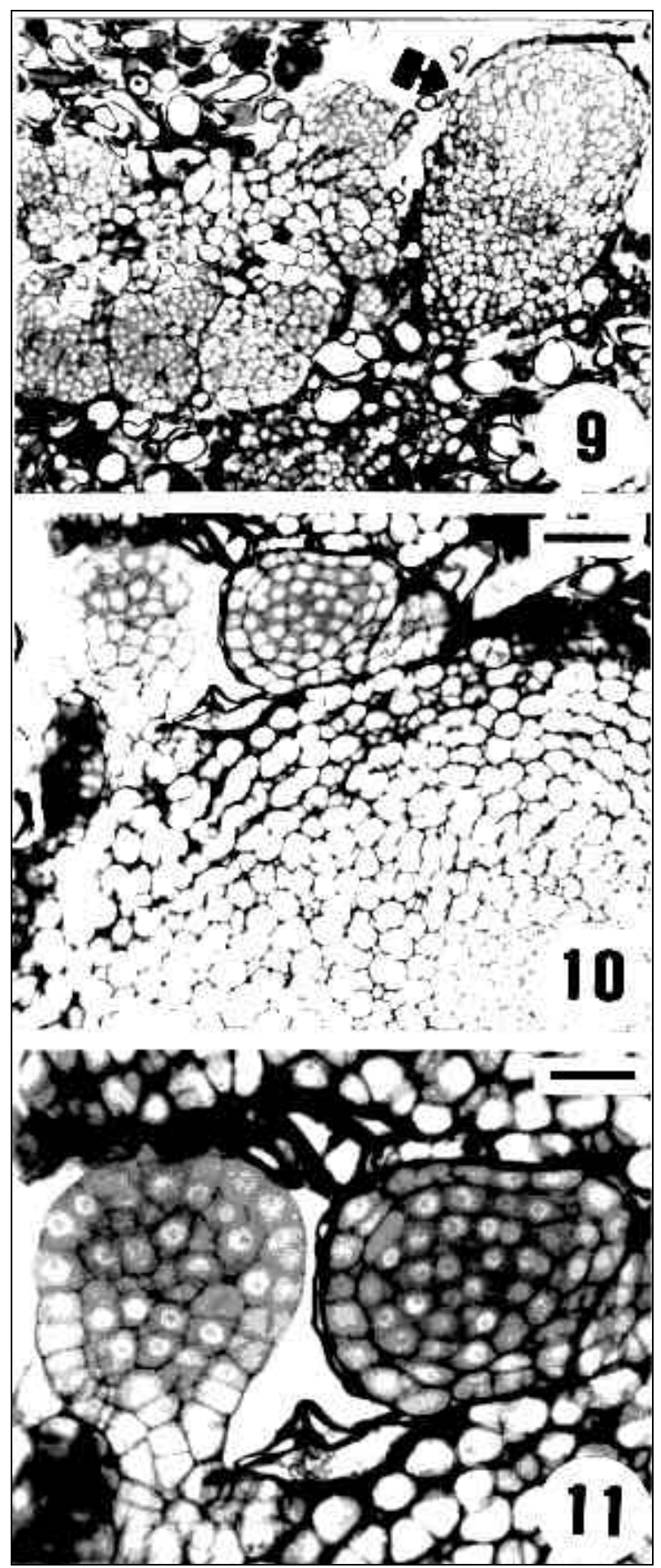

Figures 9-11 - C. papaya - Transversal sections of the callus at the $40^{\text {th }}$ and $49^{\text {th }}$ days of culture. It is possible to observe pre-embryonic complexes (Fig. 9, bar $=100$ $\mu \mathrm{m})$ and the formation of somatic embryos from the superficial cells of the complexes. (Fig. 10 bar $=57$ $\mu \mathrm{m}$; Fig. 11 bar $=30 \mu \mathrm{m})$. 


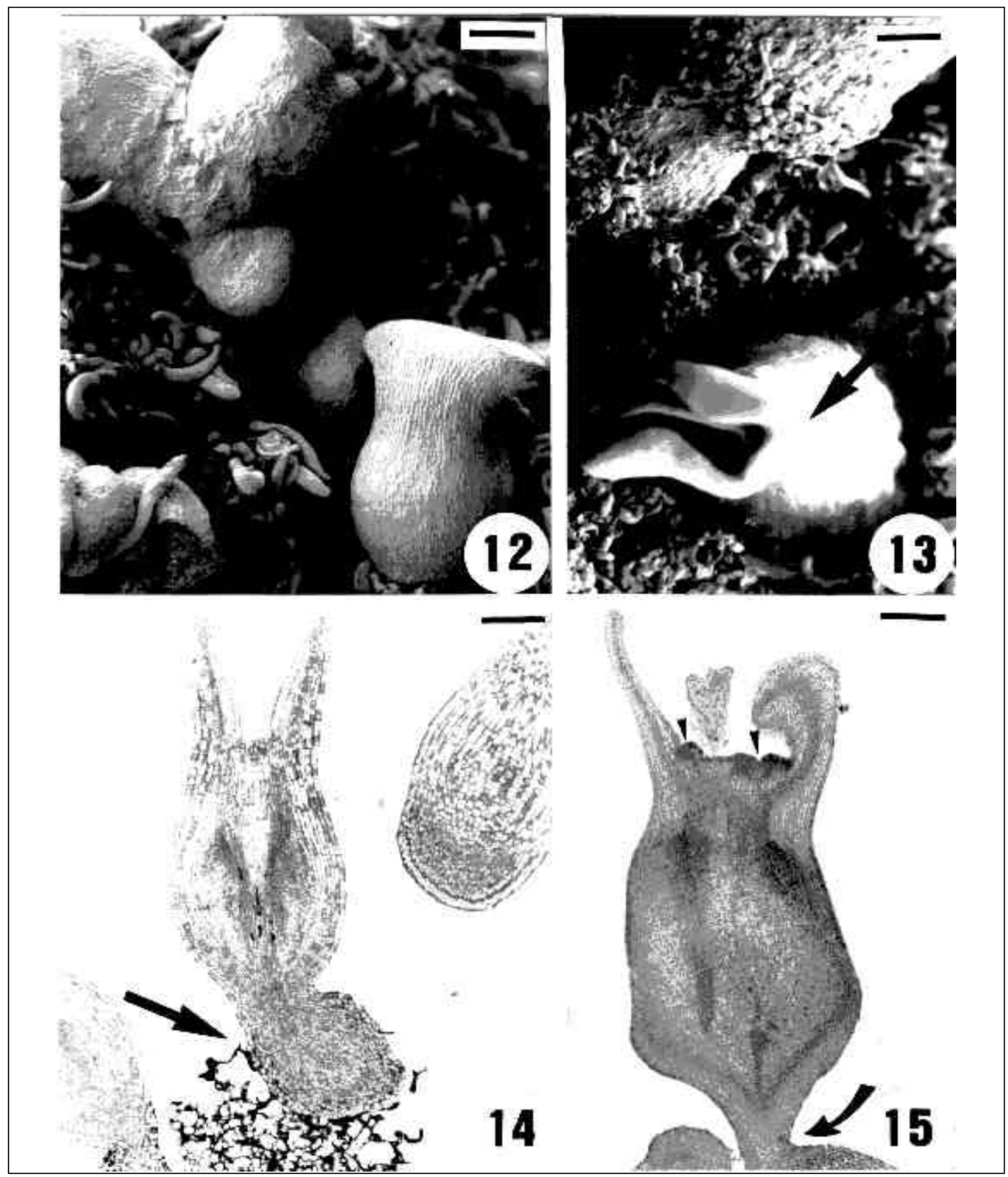

Figures 12-15 - Callus and somatic embryos (SE) of $C$. papaya after 56 days of culture in MS medium containing 2,0 mg.L $\mathrm{L}^{-1}$ of 2,4-D. 12 and 13. Electron micrograph of SE linked by their basal portion (arrow) (Fig. 12, bar = $100 \mu \mathrm{m})$ and a multicotyledonary cylindrical SE (Fig. 13, bar $=250 \mu \mathrm{m}) .14$ and 15 . Longitudinal sections of SE linked to the pre-embryonic complex by its basal portion (arrow) (Fig. 14, bar $=310 \mu \mathrm{m}$ ) or by a suspensor-like structure (Fig. 15 arrow, bar $=198,9 \mu \mathrm{m}$ ). In Fig. 15, the arrowheads show the meristematic areas in the caulinar pole. 


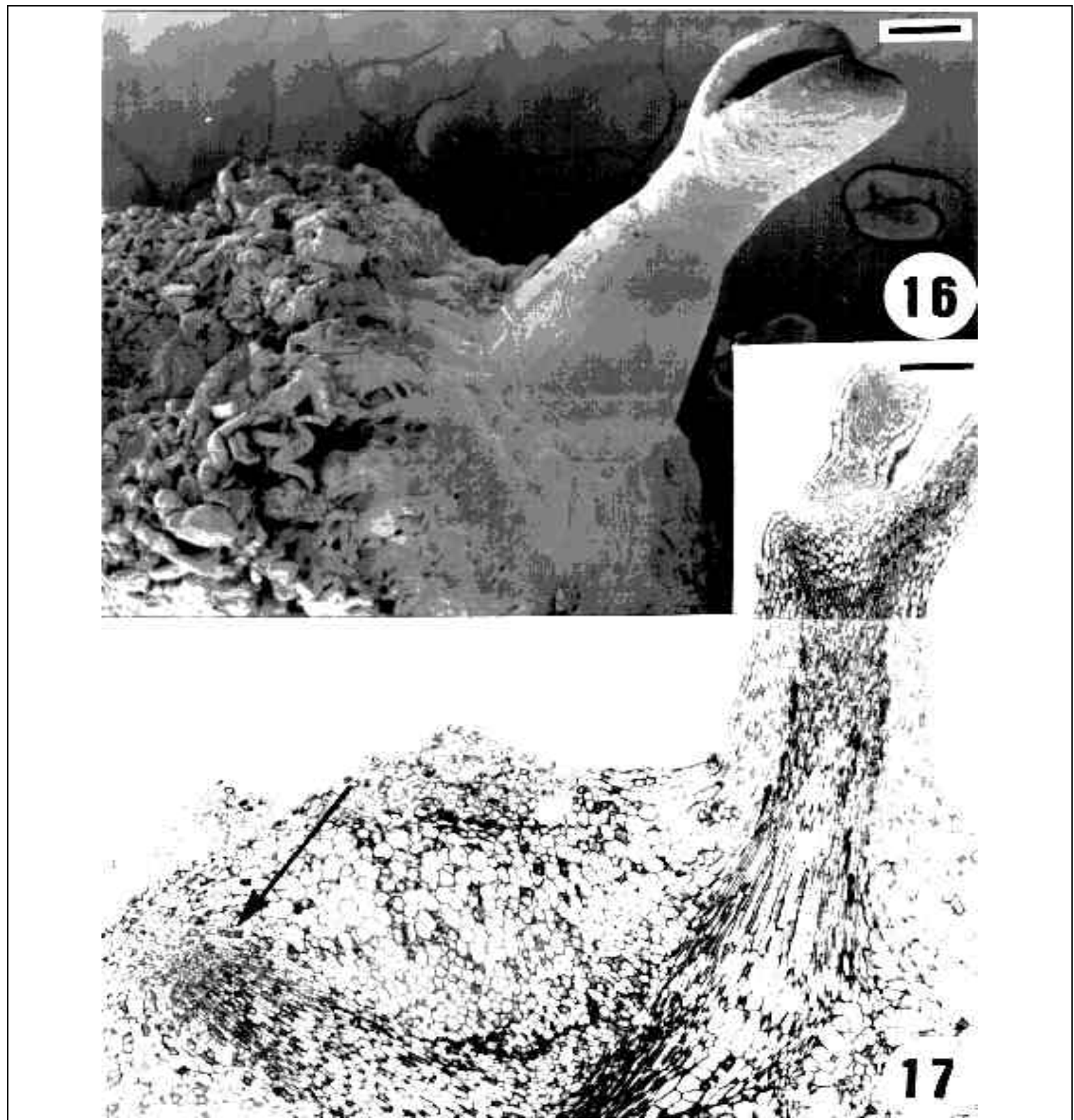

Figures 16-17 - Electron micrography of a callus of $C$. papaya showing an somatic embryo (SE) linked to the callus by the basal portion ( $\mathrm{bar}=250 \mu \mathrm{m}$ ). 17. Longitudinal section of the SE showed in the previous figure, the arrow indicates the radicular pole $(\mathrm{bar}=270 \mu \mathrm{m})$.

above, may probably be associated with the origin of the somatic embryos, as it was verified by $\mathrm{Hu} \&$ Sussex (1971) for Ilex aquifolium. According to the authors, the somatic embryos were linked by a narrow organ similar to a suspensor and appeared to be originated superficially. On the other hand, the ones that showed wide connection with the callus may be originated from meristematic areas located at the inner regions of the callus.

Somatic embryos of $C$. papaya showed morphologic variations: trumpet and cotyledonary somatic embryos with or without shoot apex (Figure 14), cylindrical somatic embryos without shoot apex (Figures 16 and 17) and somatic 
embryos with multiple foliar structures (Figures 13 and 15). Cylindrical embryos usually presented poorly developed shoot apex, while only densely stained meristematic cells were observed. Similar shoot apex formation was described by Liu et al. (1993) as juvenile apical meristem. Wetzstein \& Baker (1993) and Lazzeri et al. (1987) observed that the ability of somatic embryos to germinate is closely related to embryos of normal morphology. The lowest conversion rates of somatic embryos into plantlets were observed in somatic embryos without shoot apex (Buchheim et al., 1989; Wetzstein \& Baker, 1993). Although these plants were atypical in appearance (multiple branches and fused stems), they did not require any additional time for conversion or acclimatization compared to plants with a normal appearance (single axis).

\section{ACKNOWLEDGEMENTS}

We thank Fundação de Amparo à Pesquisa do Estado de São Paulo (FAPESP) for the financial support and Professor Elliot W. Kitajima from the Microscopic Centre of Escola Superior de Agricultura "Luiz de Queiroz" for facilities for the electron microscope analysis.

\section{RESUMO}

Embriões zigóticos maduros de Carica papaya L. 'Sunrise Solo' foram utilizados como explantes para indução da embriogênese. Estes explantes foram inoculados em meio de cultura de Murashige \& Skoog suplementado com 2,0 mg. $\mathrm{L}^{-1}$ de 2,4 ácido diclorofenoxiacético (2,4-D) e mantidos no escuro em câmara de crescimento à temperatura de $21^{\circ} \mathrm{C}$ por período de tempo variável. Através da análise histológica foi possível verificar que os primeiros embriões somáticos formaram-se diretamente a partir de células únicas da epiderme hipocotiledonar do explante após o $18^{\circ}$ dia de cultura. Porém, os demais embriões somáticos originaram-se indiretamente a partir de células superficiais de complexos pré-embriônicos presentes nas camadas periféricas e internas do calo após o $49^{\circ}$ dia de cultura. Foram detectadas algumas diferenças morfológicas entre os embriões somáticos obtidos.

\section{REFERENCES}

Barciela, J. and Vieitez, A. M. (1993), Anatomical sequence and morphometric analysis during somatic embryogenesis on cultured cotyledon explants of Camellia japonica L. Ann. Bot., 71, 395-404

Buchheim, J. A.; Colburn, S. M. and Ranch, J. P. (1989), Maturation of soybean somatic embryos and the transition to plantlet growth. Plant Physiol., 89, 768-775

Chen, M. H. and Chen, C. C. (1992), Plant regeneration from Carica protoplasts. Plant Cell Rep., 11, 404-407

Chen, M. H.; Chen, C. C.; Wang, D. N. and Chen, F. C. (1991), Somatic embryogenesis and plant regeneration from immature embryos of Carica papaya x Carica cauliflora cultured in vitro. Can. J. Bot., 69, 1913-1918

Chen, M. H.; Wang, P. J. and Maeda, E. (1987), Somatic embryogenesis and plant regeneration in Carica papaya L. tissue culture derived from root explants. Plant Cell Rep., 6, 348-351

Cronquist, A. (1981), An integrated system of classification of flowering plants. Columbia Univ. Press, New York

Cruz, G. S., Canhoto, J. M. and Abreu, M. A. V. (1990), Somatic embryogenesis and plant regeneration from zygotic embryos of Feijoa sellowiana Berg. Plant Sci., 66, 263-270

Detrez, C.; Ndiaye, S. and Dreyfus, B. (1994), In vitro regeneration of the tropical multipurpose leguminous tree Sesbania grandiflora from cotyledon explants. Plant Cell Rep., 14, 87-93

Fisher, D. B. (1968), Protein staining of ribboned epon sections for light microscopy. Histochemie, 16, 92-6

Fitch, M. M. M. (1993), High frequency somatic embryogenesis and plant regeneration from papaya hypocotyl callus. Plant Cell, Tissue and Organ Cult., 32, 205-212

$\mathrm{Hu}$, C. Y. and Sussex, I. M. (1971), In vitro development of embryoids on cotyledons of Ilex aquifolium. Phytomorphology, 21, 103-7

Johansen, D. A. (1940), Plant microtechnique. Mc Graw-Hill Book. New York. 528p.

Jordan, M.; Cortes, I. and Montenegro, G. (1982/1983), Regeneration of plantlets by embryogenesis from callus cultures of Carica candamarcensis. Plant Sci. Lett., 28, 219-221

Karnovsky, M. .J. (1965), A formaldehydeglutaraldehyde fixative of high osmolality for use in electron microscopy. J. Cell. Biol., 27, 137-138 
Lazzeri, P. A.; Hildebrand, D. F. and Collins, G. B. (1987), Soybean somatic embryogenesis: effects of nutritional, physical and chemical factors. Plant Cell, Tissue and Organ Cult., 10, 209-220

Litz, R. E. and Conover, R. A. (1978), In vitro propagation of papaya. HortiScience, 13, (3), 241242

Litz, R. E. and Conover, R. A. (1983), Highfrequency somatic embryogenesis from Carica suspension cultures. Ann. Bot., 51, 683-686

Liu, C.; Xu, Z. and Chua, N. H. (1993), Auxin polar transport is essential for the establishment of bilateral symmetry during early plant embryogenesis. Plant Cell, 5, 621-630

Maheswaran, G. and Williams, E. G. (1985), Origin and development of somatic embryoids formed directly on immature embryos of Trifolium repens In Vitro. Ann. Bot., 56, 619-630

Mahon, R. E.; Bateson, M. F.; Chamberlain, D.A.; Higgins, C. M.; Drew, R.A. and Dale, J.L. (1996), Transformation of an australian variety of Carica papaya using microprojectile bombardment. Aust. J. Plant Physiol., 23, 679-685

Matsumoto, T. K.; Webb, D. T. and Kuehnle, A. R. (1996), Histology and origin of somatic embryos derived from Anthurium andraeanum Linden ex André Lamina. J. Am. Soc. Hortic. Sci., 121, 404407

Mukhopadhyay, A.; Arumugam, N.; Nandakumar, P. B. A.; Pradhan, A. K.; Gupta, V. and Pental, D. (1992), Agrobacterium-mediated genetic transformation of oilseed Brassica campestris: Transformation frequency is strongly influenced by the mode of shoot regeneration. Plant Cell Rep., 11, 506-513
Murashige, T. and Skoog, F. (1962), A revised medium for rapid growth and bioassays with tobacco tissue cultures. Physiol. Plant., 15, 473-497

Oka, S.; Saito, N. and Kawaguchi, H. (1995), Histological observations on initiation and morphogenesis in immature and mature embryo derived callus of barley. (Hordeum vulgare L.). Ann. Bot., 76, 487-492

Roeser, K. R. (1972), Die Nadel der SchwarzkieserMassen produkt und Kunstwert der Natur. Mikrokosmos, 61 (2), 33-36

Sakai, W. S. (1973), Simple method for differential staining of parafilm embedded plant material using toluidine blue 0. Stain Technol., 48, 247-249

Sass, J. E. (1951), Botanical microtechnique. Iowa State University Press. Ames. 228p.

Tisserat, B. and DeMason, D. A. (1980), A histological study of development of adventive embryos in organ cultures of Phoenix dactylifera L. Ann. Bot., 46, 465-472

Wetzstein, H. Y. and Baker, C. M. (1993), The relationship between somatic embryo morphology and conversion in peanut (Arachis hypogaea L.). Plant Sci., 92, 81-89

Williams, E. G. and Maheswaran, G. (1986), Somatic embryogenesis: factors influencing coordinated behavior of cells as an embryogenic group. Ann. Bot., 57, 443-462 